\title{
HISTORICAL AND CONTEMPORARY CONDITIONS OF GERMAN EXPANSION TOWARDS THE CENTRAL AND EASTERN EUROPE
}

\section{İbrahim S. CANBOLAT*}

\section{Abstract}

In this paper, Germany's Foreign Policy towards the Central and Eastern Europe is going to be investigated along the contours of the framework within which historical and cultural background, fundamental means of German Foreign Policy, the pursuit of German national interests in that region and the related problems to these are to be analysed. Conceptually, the approach of conditional reality which aims to search dynamic conditions of being a political and economic power in the past and present will be used. By means of this conceptual framework, the issue of German expansion towards Balkans, and its consequences are to be analyzed.

Thanks to the discernible language they speak, after they appeared with their political identity on the stage of Europe, beginning with the $10^{\text {th }}$ century, Germans led the Holy Roman Empire on the one hand and expanded towards the Eastern Europe on the other hand. This German expansion towards the East, known as "Ostsiedlung-settlement in Eastern Europe", occurred with the aid of princes, priests, and merchants. Consequently, new settlements, institutions (churches, schools, administrative structures) and commercial relations were established in Eastern Europe.

Foreign policy has always had a privileged status in German politics and public administration. This is mostly related to the retrospective dispersion of Germans. It has become imperative to determine foreign policy, consistent with the features of the era. It should be stated that because of its tragic historical experiences, Germany is quite careful and cautious in its foreign policy practices. This may also have a significant function in German politics towards the Balkans.

European Union's common policies in this point have a constructive and appeasing effect. In fact, the EU system has a two-dimensional function both for

* Prof. Dr., Uludağ University, Department of International Relations, e-mail: icanbol@hotmail.com 
Germany and Europe. The first one is the EU's implementation of a duty of supervising Germany and stopping possible German aggression. The second one is related with and convenient for German national interests. The EU model is legitimizing German attitudes and policies towards the Europe and the Balkans.

Additionally, related with the regional and global security, Germany played its first important role in this region in post-Cold War era with its military existence in 1999 during the NATO intervention to Kosovo. Because of its historical legacy, a great number of states in Central and Eastern Europe have had political prejudices against Germany. But conditional reality which has historical and contemporary foundations has directed Germany towards integration in Europe, and thus it has made social and political reconciliation within the European Union visible. The realm of German existence with political and economic influence conditionally depends on the before mentioned integration and reconciliation movements in Central and Eastern Europe.

Keywords: German principalities, Ostsiedlung, Central and Eastern Europe, European Union, conditional reality.

\section{ORTA VE DOĞU AVRUPA'YA DOĞRU ALMAN AÇILIMININ TARİHSEL VE ÇAĞDAŞ BELİRLEYICCILERİ}

$\ddot{O}_{z}$

Almanlar, konuştukları dilin de ayırt ediciliğiyle, onuncu Yüzyıldan itibaren Avrupa sahnesinde siyasî kimlikleriyle ortaya çıktıktan sonra bir yandan Kutsal Roma Imparatorluğu yönetiminde söz sahibi olurken, diğer yandan da Doğu Avrupa'ya doğru bir açılım politikası izlemişlerdir. "Doğu Koloniciliği”" olarak bilinen Almanya'nın bu Doğuya açılımı; prensler, papazlar ve tüccarlar aracılığıyla gerçekleşiyordu. Bu gelişmeler Doğu Avrupa'da yeni yerleşim yerleri, kurumlar (kiliseler, okullar, idarî yapılar) ve ticari ilişkiler için uygun zeminin oluşmasına yol açmıştır.

Dlş politika, Alman siyasetinde ve kamu yönetiminde her zaman öncelikli bir statüye (Primat der Aussenpolitik) sahip olmuştur. Bu biraz da Almanların geçmişteki dă̆ınıklık durumuyla ilgilidir. Iç̧inde yaşanılan çağın koşullarına uygun bir diş politika belirleme zorunluluğu söz konusu olmuştur. Şu ifade edilmelidir ki, trajik tarihsel yaşanmışlıkları sebebiyle, Almanya, dış politika uygulamalarında pek hassas ve temkinli davranmak durumundadır. Bu gerçeklik Almanya'nın Balkanlara yönelik dış politikasında da önemli bir işleve sahiptir.

Avrupa Birliği (AB) bünyesinde ortak politika uygulaması bu noktada yapıcı ve uyumlaştırıcı bir etki yaratır. Gerçekte, AB sistemi Almanya ve Avrupa için iki boyutlu bir işleve sahiptir. Birincisi, Avrupa Birliği'nin Almanya üzerinde 
bir denetim görevi icra ederek olası bir Alman saldirganlı̆ğn önlemesidir. İkincisi ise Alman çıkarları için de uygun bir meşruiyet ortamının sağlanmış olmasıdir. AB Modeli sayesinde, Almanya'nin Avrupa ve Balkanlar'a yönelik tutum ve politikaları meşruiyet kazanmaktadır.

Ayrıca, bölgesel ve küresel güvenliğe ilişkin olarak, Almanya, 1999 yılında Kosova'ya yönelik uluslararası müdahaledeki askerî varlığı ile Soğuk Savaş sonrası dönemde bu bölgede ilk önemli rolünü ifa etmisstir. Tarihsel kalintılar yüzünden, orta ve doğu Avrupa'da birçok devletin Almanya'ya karşı siyasî önyarglları olmuştur. Ama tarihsel ve güncel temelleri olan Konjonktürel Gerçeklik, Almanya'yl Avrupa'da entegrasyona yöneltmiş, bu da Avrupa Birliği bünyesinde toplumsal ve siyasal bir uzlaşl biçiminde kendini göstermiş̧tir. Siyasal ve ekonomik etkiye sahip Alman varlık alanı konjonktürel olarak Orta ve Doğu Avrupa'da entegrasyon ve uzlaşlya bağll bir geliş̧me gösterir.

Anahtar Kelimeler: Alman Prenslikleri, Doğu Koloniciliği (Ostsiedlung), Orta ve Doğu Avrupa, Avrupa Birliği, Konjonktürel Gerçeklik.

\section{Introduction}

The Germans mark themselves by the language which is spoken since the 8th century in the east of the Frankish Empire. Those Deutsch/Germanspeaking people, scattered by the way of building new settlements (Ostsiedlung) in wide areas of Central and Eastern Europe, looked in vain for their unified state. ${ }^{1}$ Because of the impossibility of a unified German state, several splinter states were created, therefore, a central state was not established, and thus German principalities (Fürstentümer) originated. In the German political history, the people searched always for a German state. The German expansion towards the East (Ostsiedlung) which blossoms in the Central and Eastern Europe is a result of this search whose legacy appears vividly even to observers today. All achievements of the Germans in Central and Eastern Europe normally took place as a result of the efforts of the princes to acquire political and economic existence in the region (Kunze and Wolff, 1964: 29). This explains the meaning of the principalities in German history

\footnotetext{
${ }^{1}$ Also the German universities, especially in the 19th century, were one of the centres of the political movement which had to the purpose to realize the German unity. With the motto "honour, freedom, and fatherland", the first German Student's Association was founded in June 1815 in Jena. The students carrying the association's flag with Black-Red-Gold which were the colors of the empire demanded the political unity of the German nation. See German Bundestag, Fragen an die deutsche Geschichte. Ideen, Kräfte, Entscheidungen von 1800 bis zur Gegenwart-Questions on German History. Ideas, Forces, Decisions from 1800 to the Present (Bonn: Bundestag Press and Information Centre, 1984): 60.
} 
which is also seen intoday's Federal Republic of Germany with 16 federal states as a reflection of the German historical reality.

Germany's long history of contact with the Central and Eastern Europe from the times of the Holy Roman Empire to the present raises the question of what characterizes Germany's fundamental perspective on the Balkans. In this paper Germany's Foreign Policy towards the Central and Eastern Europe is going to be investigated along the contours of the framework within which historical and cultural background, fundamental means of German Foreign Policy, the pursuit of German national interests in that region and their problems are to be analysed.

Conceptually, the approach of the conditional reality which aims to search dynamic conditions of being a political and economic power in history and present will be used. Within this conceptual framework, besides introduction and conclusion, the study will be conducted under five main headings. In the first part, the theoretical approach: conditional reality will be succinctly presented. In the second part, the historical and cultural origins of contemporary policy will be searched. In the third part, the priorities of German Foreign Policy under conditional circumstances will be discussed. In the fourth part, the problems of Germany's national interest pursuit in the Balkans will be investigated.Finally, in the last part, German Foreign Policy towards Central and Eastern Europe within the European Union will be analysed.

\section{The Theoretical Approach: Conditional Reality}

The conditional reality as a conceptual framework includes two main variable factors: Those are on the one hand the time and on the other hand the subject matter. By means of this approach, one could explore the conditions under which the set objectives are achieved, in other words, the probability of subject matter.

\section{Conditional Reality versus Political Realism}

In contrast to the political realism (Realpolitik), which claims that the nature of human being is bad, and so that the national interests could only be achieved with the power, the conditional reality makes a neutral perspective possible to understand the sense of events. The conditional reality is a pure reality that doesn't include any image factors removing the observer or anyone from the reality. In this way a flexible preference method is feasible instead of the onedimensional power politics in every condition.

Normally, the process of decision-making is dependent on certain condition. For a scientist, politician, or any people, it might be meaningful to encounter with a condition of having solution possibilities. But in the real world, it is very difficult to reach a condition of being in an ideal position in 
order to take a decision in equality and good conscience. Without perceiving this reality, it is not possible to conceive of a good plan for us and for the world.

The view from the conditional reality paves the way to comprehend the historical and contemporary attitude-motivation of the states. From this perspective, the attitudes of the political realists are also evident, so that the observer, or, states, could appropriately take effective measures.

\section{Historical and Cultural Origins of Contemporary Policy}

At the beginning of the 10th century, the Germans appeared on the stage of Europe with a distinguished political identity by leading the Holy Roman Empire on the one hand and expanded towards the East on the other hand. This German expansion towards the East, known as settlements in the east (Ostsiedlung), happened with the aid of princes, priests, and merchants (Kunze and Wolff, 1964: 31). Consequently, new settlements, institutions (churches, schools, administrative structures) and commercial relations were established in Eastern Europe. For instance, today's Prague University, founded in 1348, was the first university in Central and Eastern Europe established by Germans. East Europe and the Balkans were viewed as a sphere of natural expansion for Germans who do not have an ocean-transcending colonial tradition. Today, German culture and German minorities intensely exist in a huge territory from east of Czechia to Romania and Ukraine. This historical and contemporary reality has a significant impact on Germany's policies towards the Balkans.

It is paradoxical that the German cultural world spreads in Central and Eastern Europe, but still, no comprehensive and unified German state came about. The Germans who not created an ideal unitary state according to their cultural and demographic structure want to be accepted with own legacy in Eastern Europe. ${ }^{2}$ One of the first German universities, the University of Prague, established in 1348 and thus 300 years before the Thirty Year's War, today is located in the capital of a Central European state, the Czechia Only the third German university, the University of Heidelberg, established in 1386, remains within the present German borders (Liulevicius, 2009: 109).

The three million German minority groups in different countries in Central and Eastern Europe, on the one hand, and the cultural legacy in the region mentioned above, on the other hand, prevent Germany from ignoring the Balkans. That is the historical background. Besides that, for example, the

\footnotetext{
${ }^{2}$ See for detailed information with respect to this theme Ibrahim S. Canbolat (2009) Değissen Dünyada Almanya ve Türkler: Ulusal Çıkar Ulusal Birlik ve Kamuoyu Tercihi Açısından Bir Inceleme (Bursa: Alfa Aktüel); Peter Reichel (2005) Schwarz-Rot-Gold. Kleine Geschichte deutscher Nationalsymbole, Bundeszentrale für politische Bildung, Bonn, p.114.
} 
refugee issue in this region does play a significant role in the present attitude of Germany towards the Balkans.

Germany was not united politically, but culturally. "From the common language, poetry, and history the concept of a uniform German national culture was developed...Leaving aside political reality romanticism discovered the German 'national spirit' (Volksgeist). The German science of history gained impetus from the recourse made to the romantically glorified past, as contrast to the bleak present" (German Bundestag, 1984). German philosophy and language were researched as a unifying feature of a nation so that those lead to a national rebirth on the basis of cultural unity.

German East settlement (Ostsiedlung) takes place mainly in the period between 1125 and 1350. Lothar von Sachsen, German King (between 11251137) and Roman Emperor since 1133, began the German settlement movement that lasted more than 200 years and which in turn changed the political, economic and social life of Germany and Eastern Europe substantially. Heinrich the Lion, Duke of Saxony and Bavaria, in the 12th century, Christianized the Slavic areas where he promoted settlement and trade, and expanded the German influence to the east. In the same century, Heinrich VI who was crowned as Roman-German King since 1169 and as the RomanGerman Emperor of the Holy Roman Empire since 1191 wanted to realize the thoughts of the supremacy of the German Empire about the Christianity. In the years 1195 and 1196, Heinrich VI tried to convert the empire into a hereditary monarchy. Nevertheless, he failed because of the opposition of the imperial princes. He was seen as a successful ruler, but also as an unprincipled power politician who expanded his fief supremacy to the east, and claimed all the Balkans (Kunzel and Wolff, 1964: 29-31).

The big eastward wandering in the 13th century takes place peacefully when the German Empire shared a border in the east between the Elbe and Oder rivers with a number of Slavic people who were underdeveloped politically and economically. During this time the German settlement ground is expanded by two thirds, and the Christian-Western cultural circle is extended to the Eastern Europe. The Slavic princes welcomed the colonists especially for the cultivation of wasteland. Village and town foundations, as well as trade, brought economic advantages to the princes (Canbolat, 2009: 90-1). Therefore, the achievements of the colonists and their legal position positively influence the rural population of Eastern Europe. The princes in the colonized areas were able to build up a modern form of land rule because they were not restrained by traditional feudal interests. Hence, the dynasties of several principalities in Eastern Europe won in the policy of German Empire influence. 
The strengthening of the prince is a particularity of German history which leads to the dualism between the king and the prince. Unrestricted sovereignty of the prince resulted in German sectionalism, or, separateness. Relating to this, the German history points out two opposite trends. First, as Kunze and Wolf ascertain (Kunze and Wolff, 1964: 33) the monarchy, on the one hand, tries to build anew its power with the acquisition of strong power, while the princes, on the other hand, want to weaken the centralized power and elevate their own. The basis of the rise of princely power is from the king's rights, which-during the investiture conflict, the throne confusion and the interregnum (caretaker government)-was transferred to the princes. The electoral king of the late medieval times is dependent with all important office actions on the approval of the electors (princes). His area of responsibility was limited and intervention in the territories was almost impossible. Hence, the establishment of a strong national German monarchy failed above all because of the German electors and princes, and also because of the French policy against Germany which wished to see Germany weak and splintered. For instance, the King Charles IV was chosen by some of the electoral princes at Rhine on 11 July 1346 as King of the Romans, and crowned on 26 November 1346 in Bonn. Because of the terms of his election, many princes remained loyal to his opponent, Louis the Bavarian; thus he was initially not in a strong position in Germany. After he made extensive concessions to the Pope in 1347, Charles IV was named by some as a "priest's king" (Pfaffenkönig) (Preidel, 2018). Although he was later crowned as Holy Roman Emperor, Charles IV, who was literate in languages like Latin, German, Czech, French and Italian, had his main power position in Bohemia.

It was an old German tradition that the king was crowned as Roman Emperor. The first German King (Kaiser) who was also a Roman Emperor, Otto I, was crowned in 962 in Rome (Lexikon-Institut Bertelsmann, 1964: 4). The Empire (Kaisertum) had a universal meaning and claimed the political authority of the Christian world. However, it was very difficult to experience this in reality. Instead, several regional powers in the German-speaking world pursued political, economic and cultural purposes, especially in Central and Eastern Europe. But those German activities were not always for the benefit of all people in Eastern Europe. When the Greeks rose up against the Turkish government in 1821, Bavarian king Ludwig sent money and officers to Greeks who were also supported in Germany by the pro-Hellenic associations. However, this political manoeuvre of the German king which was based on perceptibly European cultural identity was against the will of Metternich who respected the "legitimacy of the Sultan's rule" because of political balance in Central Europe (German Bundestag, 1984: 95). This example shows different interest perception even among German-speaking politicians, in other words, it shows the German political diversity in Central and Eastern Europe. 


\section{Priorities of German Foreign Policy under Conditional Circumstances}

Foreign policy has always had a privileged status in German politics and public administration: Primat der Aussenpolitik. This is mostly related to the retrospective dispersion of Germans which has been mentioned above. It has become imperative to determine foreign policy, consistent to the feature of the era. Depending on the condition, militaristic, political, economic and cultural foreign policy tools have been the subject matter of German politics. It should be stated that because of its tragic historical experiences, Germany is quite careful and cautious in its foreign policy practices. Especially during the era of the Federal Republic of Germany, external culture policy was seen as an important foreign policy tool.

As the German Foreign Policy has a significant function in German policies towards the Balkans, its relevance with the historical and present background should be made clear. The Germans really have a very close relation to order, security, discipline, and perfection. The reason why Germans are so correct, so security-dependent, and so pedantic can be explained by the fact that in the course of history they have experienced so many times of confusion and dispersion that they have come to appreciate the blessings of the order and security in the German world. Some observers see even the roots for German perfectionism, German order addiction, and German security mania in the Thirty Years' War which simply was named as a "German war" (Gorski, 1999: 73). In reality, the state of lawlessness, or, ungovernability (Unregierbarkeit) lasted even more than one hundred years which began with the Reformation thesis of Martin Luther in 1517 and catastrophically developed into religious and political dissent and civil war. In Germany, lands ruled on the one hand dictatorship, arbitrary action, and social and political confusion, and on the other hand religious battles appeared as a result of Luther's thesis by which the Germans divided in the time span of more than hundred years in not only Catholic and Protestant denominations but also political rivalry (Canbolat, 2009: 3-5).

After the Thirty Years' War in 1648 lose Germany nearly half of its territories and population, and the Germans went to ruin in disunity as well as in deep uncertainty. With those "experiences in the collective memory", as Gorski, the Russian author, appositely says, look the Germans constantly for security and protection in this unpredictable (unberechenbar) world (Gorski: 1999: 74). The main factors of foreign policy are the international surroundings, the national material, human resources and finally the decision centre. Related to this and all the reasons and lessons from the history, Germans assign an especially important role to foreign policy. Consistent with the conditional reality described in introduction of this study, the Germans are inclined to 
choose the most relevant means to the issues so that their foreign policy purposes are optimally reached.

Germany has had experience with all three factors in many difficulties. Hence, the German foreign policy tools must be able to pursue the national interests under such difficult circumstances. We must realize that the German foreign affairs are based on three columns, namely on diplomacy or policy, economy, and culture. Because of the political and military restrictions, the new founded Federal Republic of Germany could count only on its culture and economy to lead its foreign policy. Only after the reunification in 1990, Germany was able to serve military means in its foreign affairs. The economic success of the Federal Republic of Germany already played a notable role in its international relations during the seventies.

Besides the economy, the external culture policy became one of the main bearers of German foreign affairs. The cultural policy was called the "third dimension", 3 and "the third stage of the international policy" (Braun, 1966: 99) or, as in the words of former Foreign Minister and Federal Chancellor Willy Brandt "the third column of the modern foreign affairs" (Arnold, 1980: 106). Basically, the external culture policy was not only a means of foreign affairs for the Federal Republic of Germany, but also for the old German foreign affairs whose roots, in general, are to be found in the German history. Nevertheless, the external culture policy has a special meaning for the post-war-Germans who have founded the Federal Republic of Germany after a tragic experience. HansDietrich Genscher, who was the longest serving Foreign Minister of the Federal Republic Germany (from 1974 to 1992), calls the external culture policy a bridge of understanding and compromise (Auswärtiges Amt, 1985: 66).

If it concerns the means of the external culture policy, we see the so-called mediator organizations (Mittlerorganisationen) whose policies and decisions are determined and financed primarily by the Federal Government. Nevertheless, management and execution are assumed by the respective organizations which are active in different areas of responsibility. Depending on the area of the problems, the means are made available. For example, the German language, the science, university study, and many socio-political problem fields can be summarized in this connection as different areas of responsibility in the German external culture policy.

The German language abroad has two functions: First, it should prove that the Germans living abroad are not alienated from their culture and language, and that German is recognized in respective lands as the language of instruction for the German minority. Secondly, the German language should be used to

${ }^{3}$ This definition comes from Hamm-Brücher. See for that Frank R. Pfetsch, Die Außenpolitik der Bundesrepublik Deutschland 1949-1980 (München, 1981): 90. 
develop an external sphere of influence for Germany. Organizations through whose contributions Germany leads external culture policy, and, therefore, also its foreign affairs can be counted as follows: Goethe-Institute, German Academic Exchange Service (DAAD), German Research Society (DFG), Alexander von Humboldt Foundation (AvH), Konrad-Adenauer Foundation, Friedrich-Ebert Foundation, Internationes, and the German Archeological Institute. The German minorities living in Central and Eastern Europe are in the middle point of the German external culture policy, in particular after the decay of the Soviet Union. The political, economic and cultural aspects in relation to the German minority in Central and Eastern Europe play a significant role and they exert a serious influence on the political decision centre in Germany. The external culture policy intends to improve the standard of living of the German minority in foreign countries so that they do not want to immigrate because of economic reasons to Germany. On the other hand, Germany also fears the possibility that the economic, political and social balance could be weakened in those lands because of the immigration of the German minority from their respective countries. To prevent this, the external culture policy of Germany also helps the Catholic and Protestant church in a humanitarian way.

Lastly, the German foreign affairs are usually carried out by the participation of several ministries which choose necessary means for their part, so that a comprehensive and complementary profit can be reached in the national interest.

\section{Problems of Germany's National Interest Pursuit in the Balkans}

Some observers notice parallelism between the recognition policy of Germany after the unification and the German war purposes in the First World War, which were to stabilize economic and political supremacy of Germany over Central Europe. Ulrich Cremer points out that while other Western powers preferred a uniform solution for disintegrated Yugoslavia, German government recognized Slovenia and Croatia on 19 December 1991, and that may be interpreted as a return to the Balkan policy of the German empire: The political coalitions at that time with Croatia and Slovenia against Serbia and the Central Europe were echoed by what seemed a German welcome for the happy return of those states (Cremer, 1999). Serbia was viewed as a troublemaker: "As people the Serbians have the same right to exist, like every other, but the right on professional peace disturbance may not be granted by the local residents" (Gudopp, 1993: 177).

However, the Serbians for their part do not think like the Germans. In any case, the impression still insists that Germany holds his right hand always in the Balkans, in particular on Serbia. For example, Serbian author Dobrica Cosic believes that the Germans carry the guilt for the fact that war once again came 
to the Balkans after the decay of the Soviet Union. Cosic sees "Croatia pampered by the Germans" as the only winner of this Balkan conflict. He states that "Serbia is the centre of every strategic policy in the Balkans" (Der Spiegel Online, 1996). Since the often reproved political behaviour of Germany about recognizing Slovenia and Croatia at the end of 1991, we observe critical posture towards Germany. Indeed, one can see that the German Balkan Policy is violently criticized in the German literature too. The political scientist Matthias Küntzel states that Germany has heated up the Kosovo conflict between 1991 and 1999 and took over the role of a protective power of the UCK (Kosovo Liberation Army). He adds that Germany has goaded the conflict in Kosovo as avant-garde between March 1998 and March 1999 and pressed for a NATO war against Yugoslavia. Küntzel believes that in 1991 the Federal government has recognized the national self-determination right of Croatia and Slovenia alone and has provoked thus the later Bosnia war decisively. In his opinion Germany, by signing the German Albanian principle explanation of 1991 "for the solution of the Kosovo question", affirmed the right of self-determination for the Kosovo Albanians and with it their de facto right on secession. He evaluates this as an announcement for a desire to divide even further Yugoslavia with the instrument of a national self-determination policy (Küntzel, 2000).

The former US Secretary of State Warren M. Christopher thinks that the Germans carry a special responsibility because of the fact that they have also persuaded the EU to recognize Slovenia and Croatia. He adds that the later war events in the Balkans are to be derived from the quick recognition of Croatia and Bosnia (Talbott, 1999). The vice Foreign Secretary of the USA, Strobe Talbott, places Germany to the centre of the present geopolitical earthquake which shatters NATO and the Balkans, and, thus literally, to the "epicentre of these processes - expansion and deepening" (Küntzel, 2000; Talbott, 1999). Referring to this comment, German author Matthias Küntzel points to the words of Brzezinski which characterized Germany as a "great power inspired by an ambitious vision" (Junge Welt, 2000). The German recognition policy of 1991 was also criticized by Johan Galtung, namely with the stress that the worst is that it was not discussed in the general public in Germany. He says that Germany in the Balkans has committed a crime. And, however, in his opinion, "not the government is the main problem, but also the muteness of the wide public in Germany".

Thus the German literature concerned with the Balkan question illustrates a violent criticism of the German government made by both the Germans and the foreigners. In Germany there are also discussions regarding the international status of the former Serbian province of Kosovo. Norman Paech, the representative of the group the LEFT in the Bundestag, explains, in contrast to the Foreign Office (Auswärtiges Amt), that "neither resolution 1244 (1999) 
nor the general international law permit the one-sided declaration of independence of Kosovo" (Die Welt, 1993). This shows that there are also disagreements among the Germans themselves about some important questions of the foreign policy. However, it should be considered that a coherent policy can hardly be achieved taking into account the ethnic and political conditions in the Balkans, in particular in ex-Yugoslavia, and the historical experience.

In contrast to the acceptance of the continuity in the German foreign affairs, some analysts state that the interests of Germany in the Balkans have today nothing in common with the traditional, geopolitically defined interests of the German empire. According to the opinion of the German authors Karl Kaiser and Joachim Krause, the German interest lies rather in the restoration of the international power and political structures as well as in the abolition of social, economic and domestic instabilities in the Balkans. (Kaiser and Krause, 1996: 177).

For instance, the massacre of Srebrenica which occurred as a war crime committed by the Bosnian-Serbian military in July 1995 exercised a lasting influence on German foreign policy, in particular on the originally pacifistic posture of the Greens. The massacre of Srebrenica caused here a consciousness change which led to the turning away from pacifistic positions. Joschka Fischer who was active afterward as Foreign Minister of Germany called the aggressions of the Bosnian Serbs the new fascism that humanity has to oppose, just like it was against the National Socialists. He suggested that if the Bosnian Muslims claim a legitimate self-defence right for themselves, so "self-defence help" must morally be offered.

To meet these challenges and to lead the possible political incidents in favour of national interests, Germany must determine his foreign policy purposes cautiously and laboriously. As a German politician concerned with to the German foreign policy said, "foreign policy must be capable of reacting to global challenges that can only be met with integrated pre-emptive measures that are also sustainable". With relation to the German foreign policy in historical context during the Cold War, we can observe that the Federal Republic of Germany aimed at a policy of detente towards Eastern Europe which then became conditioned to be part of the East Bloc. The Federal Republic of Germany sent a "peace note" to the Eastern European States and the Soviet Union which attracted the growing interest on $25^{\text {th }}$ March 1966. In the mentioned note, the Federal Republic of Germany declared its readiness for negotiations on a waiver of the applying of force to settle international disputes. With several agreements, Germany aimed firstly, to facilitate the way towards a European peace order; secondly, to reduce the reservations and prejudices about Germany in Eastern Europe (Gasteyger, 2005: 235-37). Today, we realize that 
the new East-Politics (Neue Ostpolitik) led by Willy Brandt was essential for the later development in relation to German unification.

Germany as a "cosmopolitan society" also tends to operate a foreign policy based on cultural and economic relations in order to achieve national interest in Eastern Europe and in the world. More precisely, the German interests towards the Balkans are formulated by the German Foreign Office as follows (Deutscher Bundestaghttp):

- Containment of violent ethnic conflicts as a condition for lasting stability in whole Europe.

- Prevention of poverty migration, war migration and civil war migration.

- Rooting of democracy, human rights and rights of minorities as a purpose of worth-oriented foreign policy.

- Economic interests (expandable outlet markets, investment locations).

- Cooperation and credibility of the international organizations in which Germany plays an active role.

In order to achieve those objectives without causing prejudices and opposition against Germany, the European Union's common policies have a constructive and appeasing effect. In fact, the EU system has a two-dimensional function both for Germany and Europe. Firstly, the EU implements a duty of supervising Germany and stops possible German aggression. Secondly, EU model is legitimizing German attitudes and policies towards Europe and Balkans, which is convenient for German interests. So, in this way, Germany's Balkan policies are interpreted not as an aggression of mere German nationalism but as common policies of the EU system. ${ }^{4}$

\section{German Foreign Policy towards Central and Eastern Europe within the European Union}

The European Union came into existence at the end of long historical and political experiences in Europe and a searching process which brought along great torments and destructions as well. This new governing model for the security and integration of Europe projects not only economic benefit but also a trust foundation that involves the social life with its all aspects with social, political and cultural values. Europe had a fragmented appearance in the geographical and political sense in the earlier centuries before the emergence of the European Union where peace and security have always been problematic

\footnotetext{
${ }^{4}$ About the EU system and relations with this see İbrahim S.Canbolat, Örümcek Evinde Oturulmaz. İnsan Varlık Siyaset, Ortadoğu, Türkiye, Avrupa Birliği, 17 Aralık Süreci ve 3. Boyut Figüranları, Alfa Aktüel Yayınları, (İstanbul: 2014), pp. 285-339.
} 
between states. Realpolitik based on political realism, or balance of power, had built the ground for a permanent power struggle and conflicts instead of longterm alliances in Europe (Chaunu, 1981).

After the Second World War, Europe lost its feature of being "the centre of the traditional balance of power", and the Western European countries were in neither political nor economic or military solidarity so that a political and social merger was needed to ensure peace and security in Europe. The European Union system which has structured itself in an integration process could be regarded as a value distribution system referring to David Easton's definition of politics (1965: 177). Based on this conceptual framework, we regard the European Union as a supranational political system that performs value distribution with binding decisions for all communities by transferring the national sovereignty rights to the EU's authorities. (Everything that we need to maintain our existence can be considered as value) (Canbolat, 2014: 126-264).

Some objectives of the European Union mentioned in the 1992 Maastricht and 1997 Amsterdam Treaties are especially important regarding the German Foreign Policy towards Balkans. In this sense, one of the primary objectives of the European Union is to remove the traditional national boundaries by forming an economic and social field in which a single currency is valid.

The second one is to form a European Union Identity. This is different from the classic European identity in which the key element was Christianity and the loyalty to the Medieval scholastic thought. But now the European Union, as it stated in its official documents (Treaty of Lisbon, 2007), aims to put forward its identity by means of a Common Foreign and Security Policy with a unique sense of identity.

Another objective, which is closely related to the European Union Identity, is to transform the European Union into the area of freedom, security, and justice. It is aimed to implement the free movement inside it without any obstacles by taking joint measures on the issues of irregular migration, asylum and fight against terrorism with the control of external borders. (Läufer, 2005: 34-9; Treaty of Lisbon, 2007).

We have experienced a present incident showing that the European Union acted sensitively concerning this purpose. In accordance with the Readmission Agreement between the European Union and Turkey in 2013 (Migration and Home Affairs, 2013) the EU officials have made intensive attempts for the refoulement of Syrian refugees who tried to reach to the EU countries, of course firstly to Germany, via Turkey. German Chancellor Angela Merkel visited Turkey for several times in a short time, intending to send the unexpected guests -who tried to go to the countries, namely the freedom, security and 
justice area which is to be created within the borders of the European Unionback to where they came from.

So, we can see what kind of advantage and disadvantage potentials the European Union system has regarding the Balkans under the present conditions. It will be useful to discuss the subject from this point. What type of cooperation or risk potential may be of concern in Balkans? First of all when we look at it from the European perspective, it is understood that the Balkans, as the transition area of illegal immigrants in the recent times which is a sensitive area for the European Union system also contains a ground that will allow for having a voice usually in the world along with the political and criminal risks. ${ }^{5}$

As the pioneer of the European Union system, Germany was mostly on the firing line in the period when the European Union enlarged with new members, on the one hand, and, on the other hand, the general economic and financial crisis shakes Europe. The problem which is expressed as the Euro crisis is largely resulted from the fact that Greece failed to fulfil its single currency obligations.

It is observed that some EU members in Balkans firstly expected economic and political benefits from the supranational authority instead of transferring the sovereignty rights to it in certain fields and who found some decisions risky for themselves, such as Greece, Poland, and Hungary (Canbolat, 2017: 135-46). That means that all of the above-described objectives of the European Union have not yet been fully implemented. This also shows us that the European Union is still in an integration process. This process could never end because the people's preferences and expectations in different cultures come into question. However, the continuation of the process does not imply a negation or weakness. What is important here is the existence of a joint will. The opposite of that is the will of disintegration and conflict, in that historical experiences get people away from this in Europe and the Balkans.

\footnotetext{
${ }^{5}$ On 17 May 2018, at the EU-Western Balkans Summit in Sofia, the EU leaders agreed on the Sofia Declaration, to which the Western Balkans partners aligned themselves, and which includes the commitment to enhance significantly operational cooperation in the fight against international organised crime in priority areas such as drugs, migrant smuggling and trafficking in human beings. The Western Balkans region remains one of the sources of illicit arms trafficking into the Union. See $<$ https://www.consilium.europa.eu/media/34776/sofiadeclaration_en.pdf $>$, (22 November 2018). On 13 June 2018 the Commission and the High Representative of the Union for Foreign Affairs and Security Policy presented a Joint Communication to the European Parliament and the Council on elements towards an EU strategy against illicit firearms, Protecting Citizens'. See $<$ https://eeas.europa.eu/sites/eeas/ files/joint_communication_elements_towards_an_eu_strategy_against_illicit_firearms_small _arms_light_weapons_and_their_ammunition.pdf $\overline{\mathbf{f}}>, \overline{(22}$ November $20 \overline{1} 8)$.
} 
Here we can give the situation of Poland as an example. Poland Prime Minister Donald Tusk criticized Germany a few years ago for the decisionmaking process in the EU (Traynor, 2011). In this attitude of Poland, we see that the historical and traditional threat perception is still alive in a system where rights of national sovereignty are transferred to a High Authority. However, interestingly, Poland's then foreign minister Radoslaw Sikorski called 2011 for the decisive German leadership in the EU. In this sense, he said the following: "I will probably be the first Polish foreign minister in history to say so, but here it is: I fear German power less than I am beginning to fear German inactivity." He added, Poland was looking for decisive German leadership in the European Union, not domination (Stephens, 2017).

\section{Why German leadership is significant for the Balkan states?}

Contemporary, the Greek debt/euro crisis and the flow of Syrian refugees into Europe have started a debate about Germany's role in the European Union. The German interest in Balkans, especially in Serbia and in Greece, seems since 2011, remarkably high when the migration crisis in Europe has led to the intense discussions. Through a diplomatic initiative named Berlin Process which established in August 2014, Germany has tried to support Serbia's relations with EU and to help facilitating the dialogue between Serbia and Kosovo. Also the Euro crisis in Greece and generally in Europe threatened Germany's economic stability, so that it "had to take the lead on the EU's policy toward the Balkans and help the region avoid economic problems that could destabilize these countries and pose a security threat throughout Europe" (Colibasanu, 2017). For this reason, the accession of the Balkan states into the EU can be regarded as beneficial for Germany.

As a proactive and constructive actor of the EU, Germany can constitute a counterweight in the European Union and in Europe as well. "By putting its considerable influence in the service of a cohesive, strategically focused foreign and security policy", as Wolfgang Ischinger incisively wrote, Germany would "simultaneously achieve two key objectives: a stronger and more capable EU and a more European Germany" (Ibid). Under these conditions, contrary to the history, Poland and other Balkan states no longer need to fear Germany that has a leading position in the EU. Germany has an enormous commitment to the European Union that makes possible to share peace, security, prosperity and solidarity in Europe within a supranational political system. The topic of refugee and migration crisis in Europe recently dominates Germany's relations with the Balkan states in accordance with the EU's objectives. 
Now, in that condition, we can ask: what about the so-called 'German hegemony" "? If one does consider the hegemonic stability theories, s/he can see that alternative to hegemony in international relations is instability. In this sense, a hegemon leader attempts to impose norms and tends to create a system of incentives for pragmatic goals. According to Kindleberger's hegemony definition, "a hegemonic leader is the state powerful enough to pay the costs required for cooperation and shape the rules of multilateral institutions". Referring to this, he added that a hegemonic leader "presumably wants to do it in his own behalf. A leader, one who is responsible or responds to needs, who is answerable or answers the demands of others, is forced to "do it" by ethical training and by the circumstance of position" (Kindleberger, 1986).

It could be argued that Germany in that above-mentioned meaning can play a role of hegemonic leader in the European Union. Especially its foreign policy towards Eastern and Central Europe is going to be planned and carried out by means of that kind of leadership. Also, Polish foreign minister's statement meaning that "if the European Union system is made equally dominant in the region, we will tolerate even the hegemony of Germany" could be considered within that conceptual framework.

Policies related to EU's Eastern Enlargement are providing some opportunities for Germany on the one hand and it is thought that they will be a viable acquisition for EU members on the other hand. This EU reality, in connection with Germany, is providing a balancing effect, more concretely when related to Serbia. As it is known, the Serbs, as a Slavic group, may be the most disturbed ones by the Germans' Eastward expansion among the Balkan communities. Yet, Serbs believe that their faith and culture have been affected by the domination of Turks from the east and Germans from the west. In addition, the EU system demonstrates its ability to legitimize the German policies that Serbs may doubt.

Since the beginning of the 1990s, the EU has a specific role in the improvement of the cooperation with the states of Central and Eastern Europe. Germany sees the narrower geographic space in that region as a big chance in the EU enlargement question. After the breakdown of the Soviet system, the German foreign-policy priority appears as the development of expansionary openings in this changing world. Nevertheless, it is to be noted that the German Foreign Policy's priority does include "accorded solidarity" (Banchoff, 1996) with the West while expanding to the East.

${ }^{6}$ See about that William E. Paterson, "The Reluctant Hegemon? Germany Moves Centre Stage in the European Union", Journal of Common Market Studies, 49 (1), September 2011, pp. 57-75; Christoph Schönberger, "Hegemon wider Willen. Zur Stellung Deutschlands in der Europäischen Union", Merkur, January 2012; Hans Kundnani, Germany: What Hegemon?, European Council of Foreign Relations, 8 May 2012. 
In this context, related to regional and global security, Germany after its unification played its first important role in this region in the post-Cold War era with its military participation in the 1999 intervention in Kosovo. This also should serve to improve the image of Germany. For instance, previous Chancellor Schröder explained that the German soldiers in Kosovo contributed to replace the old picture of the "historical guilt and historical crime" which were committed in the name of Germany with a new picture of Germany.

It is observed that the course which began in 1991 with the recognition of Croatia and Slovenia has continued later in relation to Kosovo. The events in former Yugoslavia were called by the German Foreign Ministry as a return of barbarism. Therefore, a higher penetrating power of common action against such crimes is seen as necessary (Auswärtiges Amt, 1993: 406).

German Foreign Minister Klaus Kinkel believed in the 1990s that in the light of the inclination of the states of Central and Eastern Europe and the former Soviet Union to democracy, rule of law and market economy so, in a changed world, political and military drafts must be developed anew. Also he spoke of an "enlarged security" which connects "political, economic and military elements to a conclusive draft" and states that such a draft of the "enlarged security" cannot end on the classical alliance borders: "In radically changed Europe, in a quickly changing world, Germany must become according to his interests in future also in the security policy an export nation" (Auswärtiges Amt, 1993: 405). Kinkel sees the chance for peace in Europe, primarily not in a militarization of the foreign affairs, but in the precedence of the political conflict solution; this is valued as a security policy of the prevention which exists on the basis of early recognition and preventive diplomacy. But for the effectiveness of the preventive diplomacy, the deterrence is viewed as necessary: "Not to have to fight, one must be able to fight" (Auswärtiges Amt, 1993: 408). Thus the Foreign Office represents the view that the guarantee of the lasting peace after the end of the East-West conflict depends on the possibility to use armed forces if necessary. They are highly valued as an indispensable component of a preventive security policy. Thus, the background and the main motives of the German political as well as military intervention in Kosovo in the 1990s can be easily understood. German politics-makers believe that the new democracies in Central and Eastern Europe need a sign of German solidarity: "They need a clear orientation and visible proofs of the fact that the rearrangement painful for them is worthwhile.

However, the German solidarity described can contribute only then to the mutual interest in Eastern Europe if it undertakes to follow the necessary balancing norms which result from the historical experiences and the present realities. Therefore, the EU as a value allocation as well as worth-sharing system (Canbolat, 2014) plays an indispensable role here. 


\section{Conclusion}

Through analysis conducted under five headings above, both the connection between those and Germany's gravity and significance in Balkan politics has been discussed. First of all, it is clear that in the experiences of history and its lessons on the one hand and the political and institutional change in Europe since the 1990s on the other hand, Germany used selective politics to engage in the East without damaging the harmony with the West alliance thereby.

Germany's historical and cultural identity as well as the political circumstances in Europe today lead more or less to the fact that Germany does not act as an unrestrained great power which is searching for a life space (Lebensraum), but it does take over the role of a quasi "mediator between West and the East" (Davis, 1996). Because of the past historical legacy, many states in Central and Eastern Europe and beyond still have political prejudices against Germany. The Conditional reality which has historical and contemporary foundations has directed Germany towards integration in Europe, and thus it has made social and political reconciliation within the European Union visible on several levels. Within this context, the EU can perform best at accomplishing the founding goals of Germany and the joint tasks with other regional countries.

After it had to endure political and psychological detriment originating from its historical guilt as well as deep prejudices, the Federal Republic of Germany wants to develop the closest possible collaboration in different areas with the Eastern European countries which might act as members or neighbors of the EU. For that, Germany needs alternative politics and strategies as well as fruitful suggestions. To fulfil this need, some mediating organizations also work beside the government. Referring to some previous findings, we would say that from the German view, the credibility of the German and European Foreign affairs and the development of the Balkans are closely interlocked, thus redoubled efforts to bring those factors into closer conversion are necessary for a common future in Europe.

However, in relation to the Balkans, Germany is especially concerned with the problems of the high number of refugees, the organized crime and the corruption that it believes them to prevent a coherent economic policy and functional collaboration. Consequently, since the beginning of the 1990s, Germany, in particular under the government where Gerhard Schröder as Chancellor and Joschka Fischer as Foreign Minister was served, has worked for political and economic stability in the Balkans and for the integration of the Balkan countries into the European Union. German Foreign Minister Fischer has given particular emphasis to the fact that the East enlargement of the EU should be understood as a preventive security policy. On his initiative, under 
the German EU-Council Presidency on 10 June 1999, the Stability Pact for Southeast Europe was founded as an attempt "to the crisis prevention and civil conflict treatment" which focuses on the purpose of "the restoration and strengthening of peace, democracy, human rights and economic prosperity" (Joerißen, 2007: 5) in the Balkan states. The mentioned stability pact was so formed that it should remain as a forum for the regional cooperation and EuroAtlantic integration, and that its tasks are further taken over from a transformed regional cooperation council (RCC).

After German reunification, some questions have arisen about the strengthened self-confidence of the German foreign policy and about the increasing influence of Germany (Clement, 2004: 40-6) especially in Europe and also in the world, which originated from the recovery of the entire state sovereignty. Reasons for the discussion about a change of German foreign affairs come from the recognition of Croatia and Slovenia as well as the German military existence in Kosovo in 1999 and some other commitments assumed in foreign affairs.

If we look at from the view of conditional reality, so we can notice that German Foreign Policy in that circumstance does not appear as an unusual basic course change or axis slide.

Relating to the above discussed contents, we can argue that there are timeconditioned national and international factors which change according to the international political circumstances that activate the German potential foreign policy on a usual way, or generally stimulate this to an option. Finally, considering the hegemonic stability theories and the statements of Polish politicians, it could be argued that Germany regarding the relations with Central and Eastern European states shows an attitude of a hegemonic leader who is "powerful enough to pay the costs required for cooperation and shape the rules of multilateral institutions". 


\section{References:}

Arnold, H. (1980) Auswärtige Kulturpolitik, (München).

Auswärtiges Amt, Deutsche Außenpolitik Nach der Einheit 1990-1993 (Bonn: Eine Dokumentation, 1993).

Auswärtiges Amt, Unsere Auswärtige Politik (Bonn: 1985).

Banchoff, T. (1996) "Conceptual Approaches to German Policy in Europe: Making Sense of Continuity," University of California at Berkeley, Working Paper 7, 9 April 1996, Center for German and European Studies.

Braun, D. (1966) Deutsche Kulturpolitik im Ausland (München).

Canbolat, İ. S. (2009) Değişen Dünyada Almanya ve Türkler: Ulusal Çıkar Ulusal Birlik ve Kamuoyu Tercihi Açısından Bir İnceleme, (Alfa Aktüel Yayınlar1: İstanbul).

Canbolat, İ. S. (2014) Avrupa Birliği ve Türkiye: Uluslarüstü Bir Sistemle Ortaklık, 6. Baskı, (Alfa Aktüel Yayınları: İstanbul).

Canbolat, İ. S. (2014) Örümcek Evinde Oturulmaz Insan Varlık Siyaset, Ortadoğu, Türkiye, Avrupa Birliği, 17 Aralık Süreci ve 3. Boyut Figüranları (Alfa Aktüel Yayınları: İstanbul).

Canbolat, İ. S. (2017) "The European Union as an alternative security system and Turkey's relations with this system", in Y. Acer, I. Koval, M. A. Icbay and H. Arslan (eds.), Recent Developments in Social Sciences: Political Sciences and International Relations, International Association of Social Science Research Press, pp. 135-46.

Clement, R. (2004) "Die neue Bundeswehr als Instrument deutscher Außenpolitik," Aus Politik und Zeitgeschichte, B11: 40-46.

Colibasanu, A. (2017) "Germany: Keeping an eye on the Balkans", Geopolitical Futures, 29 November 2017, <https:/geopoliticalfutures. com/germany-keeping-eye-balkans/>.

Cremer, U. (1999) "Die Balkanpolitik Deutschlands", <http://www.wissen schaft-und-frieden.de/seite.php?artikelID=1368>, (19 November 2018).

Davis, P. (1996) "Marbled Diplomacy: Germany's Role in the Integration of East and West Europe", Working Paper 7, 10 April 1996, University of California at Berkeley, Center for German and European Studies.

Der Spiegel Online (1996) "In die Zwicke nehmen", 1 April 1996, $<$ http://www.spiegel.de/spiegel/print/d-8906670.html>, (21 April 2016). 
Deutscher Bundestag (n.a) <https://www.bundestag.de/dokumente/>, October 2018).

Die Welt (Newspaper), 18.03.1993.

EU-Western Balkans Summit (2018) Sofia Declaration, 17 May 2018, $<$ https://www.consilium.europa.eu/media/34776/sofia-declaration_en.pdf $>$, (22 November 2018).

Gasteyger, C. (2005) Europa zwischen Spaltung und Einigung, Bundeszentrale für Politische Bildung, (Bonn).

German Bundestag (1984) Fragen an die deutsche Geschichte. Ideen, Kräfte, Entscheidungen von 1800 bis zur Gegenwart-Questions on German History. Ideas, Forces, Decisions from 1800 to the Present (Bonn: Bundestag Press and Information Centre, 1984).

Gorski, M. (1999) Gebrauchsanweisung für Deutschland, (München: MünchenR. Piper GmbH \& Co. KG).

Gudopp, W. D. (1993) Auf dem Weg in den Dritten Weltkrieg? Verein Wissenschaft und Sozialismus, (Frankfurt: Main).

Ischinger, W. (2015) “Germany’s Hegemony Trap”, 14 September 2015, $<$ https://www.securityconference.de/en/news/article/germanys-hegemonytrap/>, (20 November 2018).

Joerißen, B. (2007) "Der Balkan. Von Krieg, Frieden und Europa", Kompas 2020, Deutschland in den internationalen Beziehungen. Ziele, Instrumente, Perspektiven, Friedrich-Ebert-Stiftung, January 2007 (5).

Joint Communication to The European Parliament and The Council (2018), Elements towards an EU Strategy against illicit Firearms, Small Arms \& Light Weapons and their Ammunition "Securing Arms, Protecting Citizens", 13 June 2018, <https://eeas.europa.eu/sites/eeas/files/joint communication_elements_towards_an_eu_strategy_against_illicit_firearms small_arms_light_weapons_and_their_ammunition.pdf $>, \quad(22 \overline{\text { November }}$ 2018).

Junge Welt (Newspaper), 24.03. 2000.

Kaiser, K., and Krause, J. (1996) Deutsche Politik gegenüber dem Balkan: Deutschlands neue Außenpolitik, Bd. 3, Interessen und Strategien (München).

Kindleberger, C. P. (1986) "Hierarchy Versus International Cooperation", International Organization, 40 (4): 841-47. 
Krupp, H. K. (1978) Politische Geschichte der Bundesrepublik Deutschland, (Stuttgart).

Kundnani, H. (2012) "Germany: What Hegemon?", European Council of Foreign Relations, 8 May $2012<\mathrm{https} / / / \mathrm{www} . \mathrm{ecfr} . \mathrm{eu} /$ article/commentary_ germany_what_hegemon>, (20 November 2018).

Küntzel, M. (2000) Die Rolle der Bundesrepublik bei der Vorbereitung des Kosovo-Kriegs, <http://www.matthiaskuentzel.de/contents/die-rolle-derbundesrepublik-bei-der-vorbereitung-des-kosovo-krieges>, (22 April 2016).

Kunze, K. and Wolff, K. (1964) Grundwissen Geschichte, (Stuttgart: Ernst Klett Verlag).

Läufer, T. (ed.) (2005) Verfassung der Europäischen Union, Bundeszentrale für politische Union, (Bonn).

Lexikon-Institut Bertelsmann (1964) Deutsche Geschichte, (Stuttgart: Bertelsmann Lexikon Verlag).

Lippert, B. (2005) "Die Union und ihre Nachbarn nach dem Verfassungsvertrag", in Matthias Jopp and Saskia Matl (eds.) Der Vertrag über eine Verfassung für Europa. Analysen und Konstitutionalisierung der $E U$, (Baden).

Lippert, B. (2006) "Assoziierung plus gesamteuropäische Aufgabenföderation: Plädoyer für eine selbstbewusste EU- Nachbarschaftspolitik," Forum Nachbarschaftspolitik, Integration 2.

Liulevicius, V. G. (2009) The German Myth of the East: 1800 to the Present (New York: Oxford University Press).

Migration and Home Affairs (2013) "EU-Turkey Readmission Agreement signed and Visa Liberalization Dialogue launched", $<$ https://ec.europa.eu/home-affairs/what-is-new/news/news/2013/20131216 _01_en>, (22 November 2018).

NTV (2009) "EU-OstpartnerschaftStabilität für Krisenregion”, 7 May 2009, $<$ http://www.n-tv.de/politik/Stabilitaet-fuer-Krisenregion-article69724. html $>$, (25 March 2016).

Paterson, W. E. (2011) "The Reluctant Hegemon? Germany Moves Centre Stage in the European Union", Journal of Common Market Studies, 49 (1): $57-75$.

Peter Reichel, Schwarz-Rot-Gold. Kleine Geschichte deutscher Nationalsymbole, (bpb: Bundeszentrale für politische Bildung, Bonn: 2005). 
Pfetsch, F. R. (1981) Die Außenpolitik der Bundesrepublik Deutschland 19491980, (München).

"Plädoyer für eine selbstbewusste EU-Nachbarschaftspolitik" (2006) Forum Nachbarschaftspolitik, Integration 2.

Preidel, H. (2018) "Charles IV Holy Roman Emperor", $<$ https://www.britannica.com/biography/Charles-IV-Holy-Romanemperor>, (22 November 2018).

Schönberger, C. (2012) "Hegemon wider Willen. Zur Stellung Deutschlands in der Europäischen Union”, Merkur.

Stephens, P. (2017) "When German power meets Polish nationalism", Financial Times, November 16 2017, <https://www.ft.com/content/a5ecb 894-c9fe-11e7-ab18-7a9fb7d6163e>.

Talbott, S. (1999) "Das neue Europa und die neue Nato" FAZ, 5 Februaray 1999.

Traynor, I. (2011) "Polish PM accuses European leaders of hypocrisy", The Guardian,1 July 2011, <https://www.theguardian.com/world/2011/ jul/01/polish-pm-european-leaders-hypocrisy>, (15 November 2018).

Treaty of Lisbon (2007) <https://eur-lex.europa.eu/legal-content/EN /TXT/?uri=celex\%3A12007L\%2FTXT>, (23 November 2018).

Winkelmann, E. Heinrich VI. (Kaiser), in: Allgemeine Deutsche Biographie (ADB), Band 11, Duncker \& Humblot, Leipzig: 1880: 419-430. 